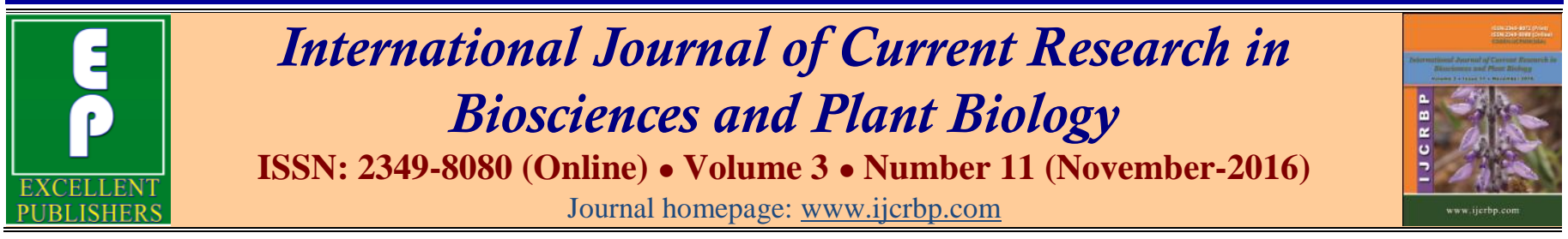

\title{
Oenothera speciosa Nutt. (Onagraceae): A New Record for the Flora of Iraq with Reference to its Faunal Associations and Insect Trapping Attributes
}

\author{
Talib O. Alkhesraji ${ }^{*}$, Naglaa M. Al-abide ${ }^{\text {and Sirwan H. Salih² }}$ \\ ${ }^{1}$ Biology Department, College of Education for Pure Sciences, Tikrit University, Salaheddin, Iraq \\ ${ }^{2}$ Biology Department, College of Education, University of Garmian, Sulaimani, Iraq \\ *Corresponding author.
}

\begin{abstract}
A b stract
Oenothera speciosa Nutt. is recorded a new for the flora of Iraq. The species was found in different places (such as private and common gardens and wasted areas) in Tikrit (Mid Iraq), Chewarta and Sulaimani (North Iraq). Geographical distributions, details of habitat, morpho-anatomical description and faunal associations of the species are given. $O$. speciosa was found to act as insect trapping plant where moths and butterflies are the most commonly trapped insects.
\end{abstract}

\section{Article Info}

Accepted: 29 October 2016

Available Online: 06 November 2016

\section{Keywords}

Faunal associations

Oenothera speciosa

Onagraceae

\section{Introduction}

The family Onagraceae have a worldwide distribution, mainly in the new world, especially Western North America (Levin et al., 2004), comprises 17 genera and about 655 species (Levin et al., 2003). In Iraq the family is represented by 7 genera (Circaea, Clarkia, Epilobium, Fuchsia, Jussiaea, Ludwigia and Oenothera) (Al-Rawi, 1964; Chakravarty, 1976; Raven, 2013). Oenothera L. (tribe: Onagreae) is the second largest genus of the family Onagraceae consists of 145 species, divided into 18 sections, 5 of which are subdivided into subsections (Wagner et al., 2007). These species are native to North and South America, some of them are widely naturalized throughout temperate parts of the world (Dietrich et al., 1997; Wagner et al., 2007; Chen et al., 2007a). Oenothera genus was not mentioned in Onagraceae in Flora of Iraq (Raven, 2013). However, Chakravarty (1976) reported two species cultivated in Iraq, $O$. whitenyi A.Gray and unidentified one with yellow flowers open at evening (Locally called Maghribi). In the present paper, Oenothera speciosa Nutt. (pink primrose or pink Ladies) is recorded for the first time for flora of Iraq. $O$. speciosabelongs to section Xylopleurum (Averett et al., 19 88; Tobe et al., 1987; Levin et al., 2004) or to section Hartmannia (Wagner and Hoch, 2007; Wagner et al., 2007), and is native to Southeastern United States and Mexico (Vladimirov et al., 2010; Lim, 2014). This species is one of the most frequently cultivated Oenothera species and is listed as escaped from cultivation in many areas of the world (Starr and Starr, 2011). It is known in several countries throughout Europe and Asia like Greece (Vladimirov et al., 2010), Italy (Montanari and Marconi, 2010), Sweden, Finland (Rostanski, 2006), Egypt (Marzouk et al., 2009), NorthKorea (Shin et al., 2012). There are no reports on O. speciosa from Floras of China (Chen et al., 2007a), Pakistan (Hoch and Raven, 1981), India (Matthew, 
1995), Nepal (Press et al., 1998), Taiwan (Huang and Editorial Committee, 2003) as well as from countries neighboring Iraq (Saudi Arabia, Iran, Jordan, Kuwait, Syria and Turkey). Here, we present for the first time information on the morphology, anatomy, faunal associations and insect trapping characters of $O$. speciosa from Iraq.

\section{Materials and methods}

In spring 2015, during a field trips to collect plant specimens, the authors collected specimens belonging to Onagraceae family from Tikrit (Mid Iraq, 100-120m altitude, $34^{\circ} 27^{\prime} \mathrm{N} 43^{\circ} 35^{\prime} \mathrm{E}$ ), Chewarta and Sulaimani (North Iraq, $750-800 \mathrm{~m}$ altitude, $35^{\circ} 31^{\prime} \mathrm{N} 45^{\circ} 19^{\prime} \mathrm{E}$ ) and were identified as Oenothera speciosa Nutt, according to several botanical literatures (Munz, 1965; Raven, 1968; Chamberlain, 1972; Rostanski, 1982; Chen et al., 2007a; Prigge Gibson, 2013; Lim, 2014; Hilty, 2015).
Geographical distributions of the studied species are mapped as in Figs. 1 and 2. Morphological and anatomical characters of fresh aerial parts of $O$. speciosa (stem, leaf and flower) were studied.

Plant specimens were examined by dissecting and light microscope and free hand sectioning. Sections are stained by safranin and iodine in potassium iodide (IKI). Fauna specimens were identified from morphological characters according to entomological and other faunal references (Cokendolpher et al., 1979; Heath and Emmet, 1983; Chapman, 1998; Arnett, 2000; Capinera, 2008; Macaulay, 2008; Kendall, 2009; Heppner, 2010; and Evans, 2014). Fauna from flowers of O. speciosa were collected by using net and killing jars with ethyl acetate. Insects were pinned and saved for identification. Insects trapped by host flowers were photographed by digital camera. O. speciosa specimens were deposited at Herbarium of College of Science, Tikrit University.

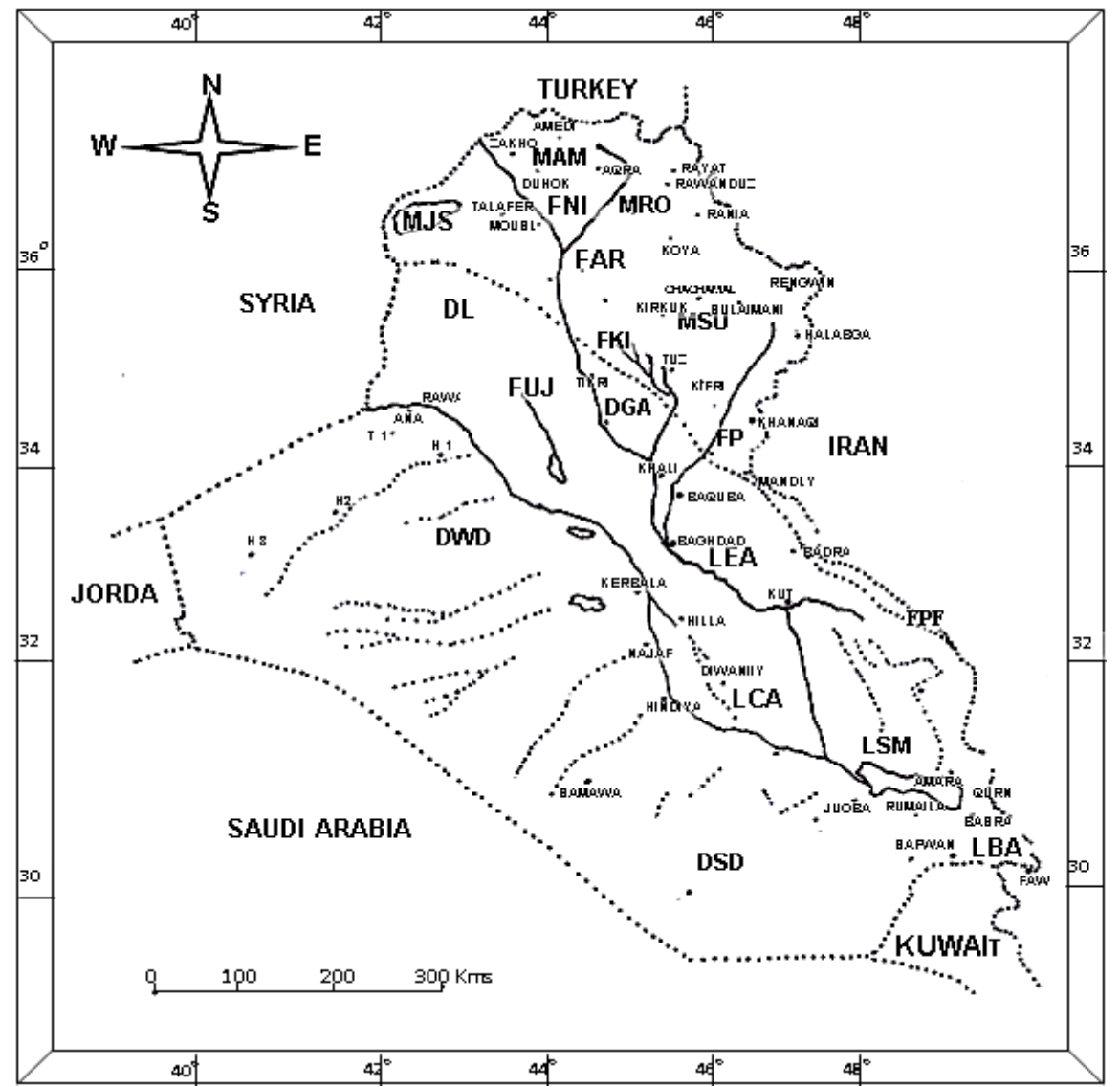

Fig. 1: Physiographic regions and Districts map of Iraq.

M - MOUNTAIN REGION F - UPPER PLAINS AND FOOTHILLS REGION MAM- Amadiya District MRO - Rowanduz District MSU - Sulaimani District MJS - JabalSigar District FPF- Persian District
FUJ- Upper Jaziera District

FNI- Nieneveh District

FAR- Arbil District

FKI- Kirkuk District
D - LOWER PLATEAU REGION L - LOWER MESOPOTAMIAN REGION

DLJ- Lower Jaziera District LEA- Eastern Alluvial Plain District DGA- Ghurfa - Adhaim District LCA-Central Alluvial Plain District DWD- Western Desert District LSM- Southern Marsh District DSD- Southern Desert District LBA- Basra Estuarine District 


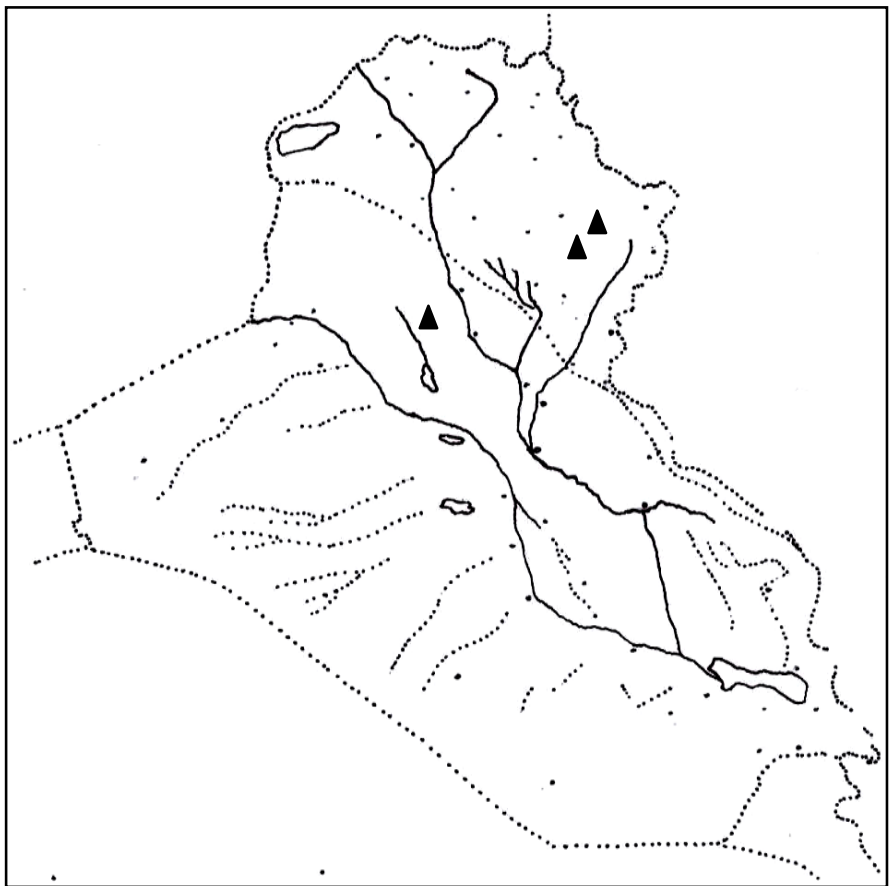

Fig. 2: Distribution map of the O. speciosa $(\mathbf{\Delta})$.

\section{Results}

Oenothera speciosa Nutt. : Int. J. Acad. Nat. Sci., Philadelphia. 2,119.

Types: Plains of the Red River-Arkansas.

Common English names: Pink primrose, showy evening primrose, Mexican evening primrose pink Ladies (Lim, 2014). Arabic: Maghribi (Al-Katib, 2000).

Synonyms: Hartmannia speciosa Small, Xylopleurum drummondi Spach, Xylopleurum nuttallii Spach, Xylopleurum obtusifolium Spach, Xylopleurum speciosum (Nutt) Raim, (Lim, 2014).

\section{Description (Figs. 3-5):}

Weakly descending to erect perennial herb, $15-55 \mathrm{~cm}$ tall, rhizomatous, with a spread of $30 \mathrm{~cm}$, rosetted when young, stem with basal and cauline leaves.

Stem: Cylindrical up to $3 \mathrm{~mm}$ in diameter, solid, simple or branched. In cross-section(c.s.): epidermis, uniseriate with cuticle, stomata and non-glandular hairs, ground tissue system composed of cortex (includes lamellar collenchyma, chlorenchyma and ordinary parenchyma) below epidermis and wide parenchymatous pith in the center of the stem, primary and secondary vascular tissues in a circular arrangement separating between cortex and pith. Leaves: Alternate, $10-60 \times 3-25 \mathrm{~mm}$, sessile or short petiolate, petiole up to10 $\mathrm{mm}$ long. Blade: Lanceolate, oblanceolate, elliptic or oblong, margin toothed or pinnatified, pinnately veined, midrib sunken on upper surface. Blade in c.s.: about $230 \mu \mathrm{m}$ thick, epidermis uniseriate, amphistomatic, pubescent upper and lower epidermis, bifacial with palisade parenchyma in 2-3 rows, vascular tissues arranged in closed collateral bundles without kranz anatomy (i.e., characteristic of $\mathrm{C} 3$ plant), midrib region $400 \mu \mathrm{m}$ thick, semicircular in shape with large central vascular bundle surrounded by ordinary parenchyma; collenchyma adjacent to upper epidermis. Petiole in c.s.: winged, plane on adaxial face, concave on abaxial face, vascular tissues arranged in crescent shape surrounded by ordinary parenchyma which in turn surrounded by two arms of chlorenchyma extending from the wings, raphide crystals present in ordinary parenchyma. Flowers: bisexual, 20-40 $\mathrm{mm}$ across emerge solitary from the axils of the upper leaves, sepal 4 , light green turning pink with age, $15 \times 3 \mathrm{~mm}$, petals 4 , broadly obovate, $25-28 \times 22-25 \mathrm{~mm}$, dark pink to white fading pinkor rosy-pink, lined with dark pink or red veins radiate outward from the throat of the flower, throat is yellowish green. Stamens: Eight, anthers pale yellow, versatile, linear 9-11 mm long, longitudinally dehiscent, filaments white, erect, glabrous, 15-16 mm long. Pistil-1, ovary, inferior up to $14 \mathrm{~mm}$ long, 8 alternating ribs, 4 of them with 2 vascular bundles each, 4 chambers each with numerous ovules, style, white, 24$28 \mathrm{~mm}$ long, densely puberulent (hairs: tapered nonglandular, with raphides), stigma 4 , white lobes like white cross, 5-10mm long, hypanthium above ovary, light green, 10-12 mm long, pubescent (internally with non-glandular hairs facing those of the style), its hairs with raphide crystals, nectary at its base. Fruit: capsule 10-14 mm long with numerous seeds. Seed: $1 \mathrm{~mm}$ long. Blooming: Mostly diurnal in both Tikrit and Sulaimanya cities.

Phenology: Flowering Mid April - July, Fruiting July August.

Habitat: Roadsides, wasted places, private and common gardens in Tikrit city and from private and common gardens in Chewarta and Sulaimanya city.In Tikrit city, the species is associated with different plants, among them,Citrus sinensis, Convolvulus sp., Cynodondactylon, Cyperus rotundus, Imperata cylindrica, Mentha sp., Medicago sp., Morus trees., Prunus arminiaca, Rosa sp. and Trifolium sp. In Sulaimanya, the associate plants include Morus and legume trees and some Asteraceae ornamental plants. 

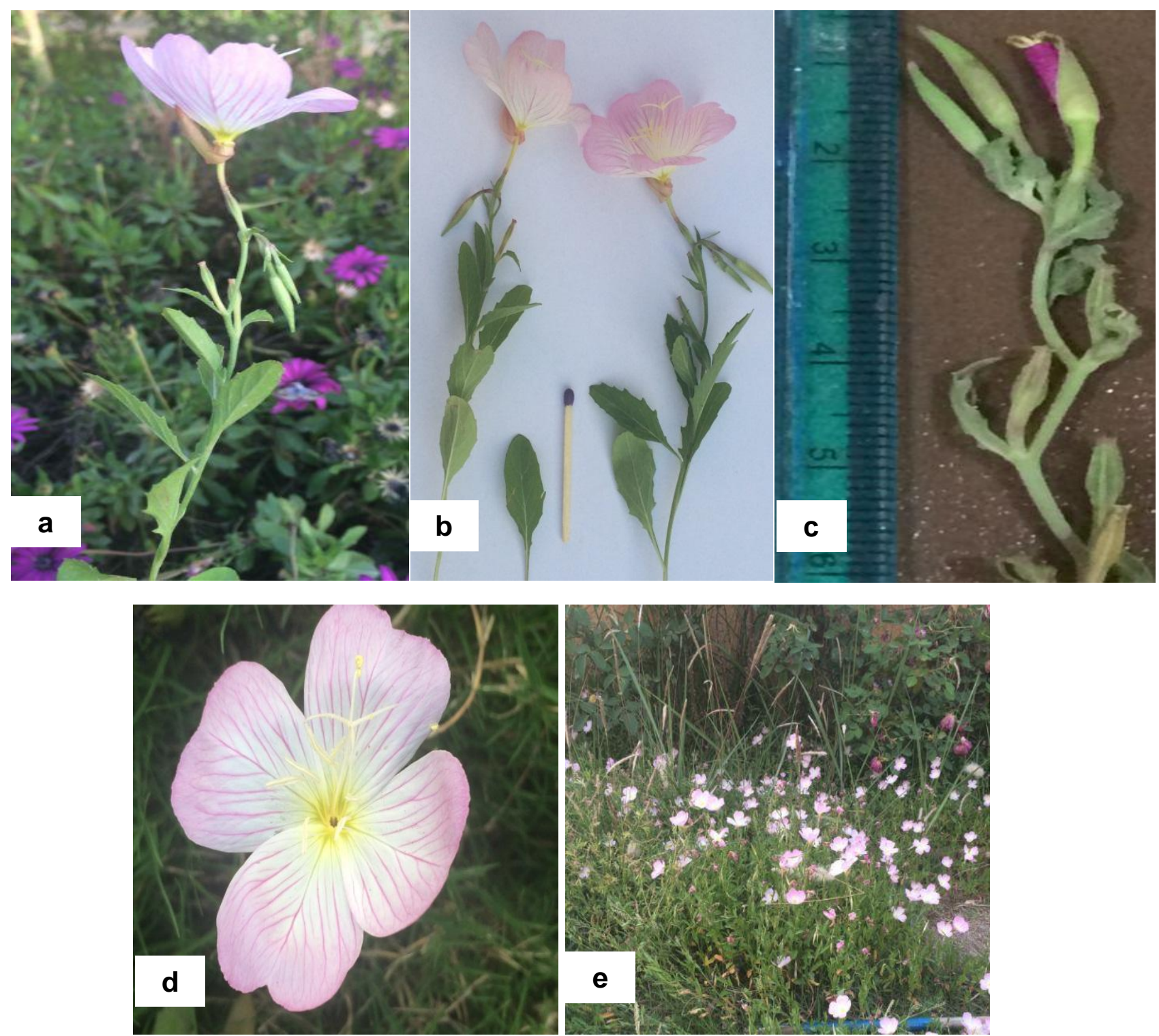

Fig. 3: .O. speciosa, a-general view; b-flowering branch; c-fruited branch with buds; d-flower; e- population of plant in private garden.

\section{Native distribution: South-Central USA.}

Faunal associations (Fig. 6): In Tikrit city include: Anthocomus sp. (Coleoptera, Malachiidae) Apis sp. (Hymenoptera, Apidae) Autographa californica (Lepidoptera, Noctuidae) Coccinella sp. (Coleoptera, Coccinellidae) Harmonia sp. (Coleoptera, Coccinellidae) Hyles livornica (Lepidoptera, Sphingidae) Macroglossum stellatarum (Lepidoptera, Sphingidae) Monomorium sp. (Hymenoptera, Formicidae) Omphaloscelis lunosa (Lepidoptera, Noctuidae) Papilio sp. (Lepidoptera, Papillionidae) Plutella sp. (Lepidoptera, Plutellidae) Vanessa cardui (Lepidoptera, Nymphalidae)
Unidentified fauna: among them, species belong to Coleoptera (from Cucurlionidae), Diptera (from Phoridae and others), Hymenoptera (others from Formicidae) and white spider (Araneae, Thomisidae).

\section{Fauna feeding behavior (Fig. 7):}

Anthocomus feeds on nectar by free entry and exit of the whole body through throat of the flower. A. californica, $H$. livornica and $O$. lunosa feed on nectar by sending their proboscises parallel (i.e., top feeding) or at right angle (i.e., lateral or side feeding) to flower axis. Papilio sp. and $V$. cardui getting nectar mostly by top feeding. Coccinella spp. and Harmonia sp. occur at throat of the flower and feed by using their mouth 
parts and front pair of legs (see Fig.6d, g). Plutella feeds by inserting its head inside the throat. Monomorium sp. feeds on nectar and parts of dead insects.

In this study, it was noticed that $O$. speciosa acting as trapping plant for all Lepidoptera insects (moths and butterflies) associated with its flowers. The most frequently trapped insects are A. californica, $H$. livornica, M. stellatarum and V. cardui. The proboscises of these insects are found trapped between the tapered hairs of both hypanthium and style and after a period of time the trapped insects die and become a prey for other faunal organisms (other insects, white spiders and domestic cats). Trapped moths are often looked as if they are hanged. In addition to moths and butterflies, nonLepidoptera visitors (such as honeybees) are also seen attacked by white spiders (Fig 6b, Fig 8).
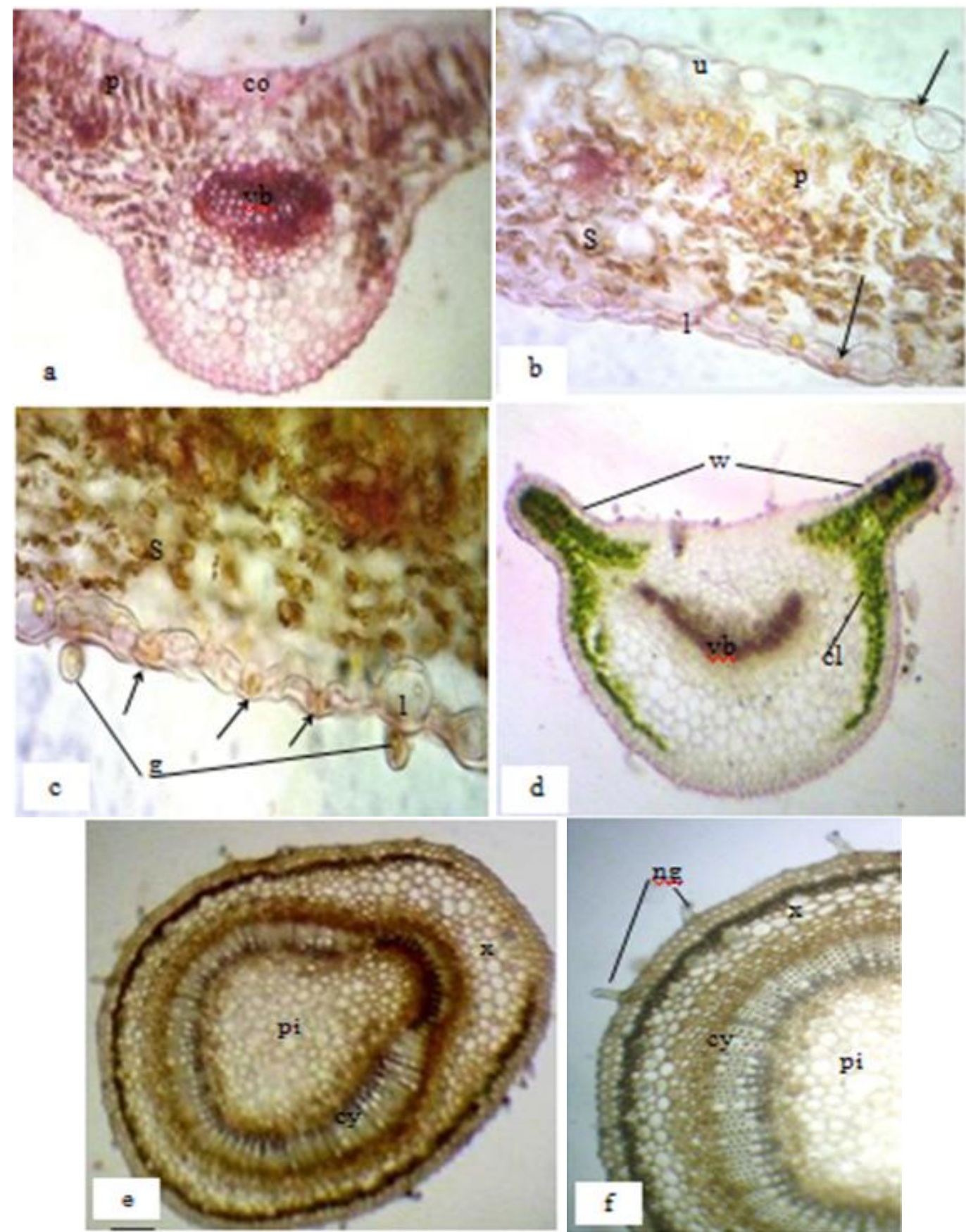

Fig. 4: O. speciosa leaf and stem anatomy. a, b, plant bifacial leaf c. s. showing midrib region (a) and stomata on both upper and lower epidermis (b); c, glandular hairs and stomata on lower epidermis; d, petiole c. s.; e, stem c. s.; f, Fig. (e) magnified. 

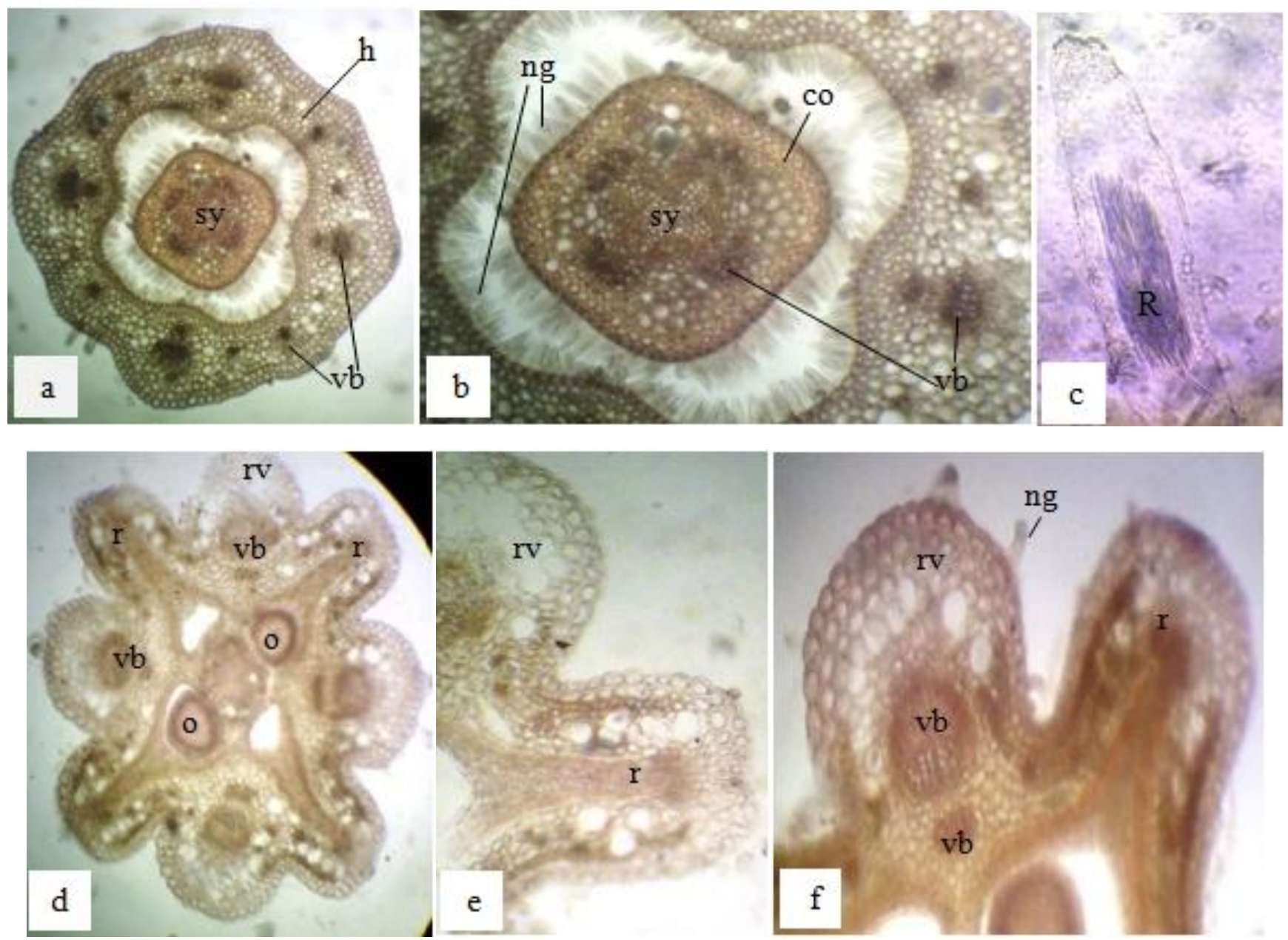

Fig. 5 . O. speciosa floral anatomy. a, hypanthium and style c. s.; b, Fig.(a) magnified (note: opposite hairs of hypanthium and style); c, hypanthium hair with raphide crystals; d, ovary c.s. showing 8 alternating ribs (note: 4 ribs with vascular bundles and others without, 4 locules and ovules ); e and f, Fig.(d) magnified (note: ovary rib without vascular bundle in (e) and ovary rib with two vascular bundles in (f). Abbreviations in Figs. a-f: h, hypanthium; b, bud; f, fruit; co, collenchyma; p, palisade parenchyma; s, spongy parenchyma; vb, vascular bundle; u, upper epidermis; l, lower epidermis ; $\uparrow$, stomata; g, glandular hair; w, petiole wing; cl, chlorenchyma; ng, non-glandular hair; x, cortex; pi, pith; cy, vascular cylinder; sy, style,; R, raphide crystal; r, rib without vb; rv, rib with vb; o, ovule.

\section{Discussion}

Oenothera is not native to Iraq. It is also not native to several other Asian countries among them those neighboring Iraq like Saudi Arabia, Iran, Syria and Turkey. O. speciosa is not recorded for floras of these neighbors as well as for floras of other Asian countries such as China, India, Pakistan and Taiwan. So the present record is the first for Iraq as well as for our region.

According to Chakravarty (1976), some Oenothera species (O. speciosa not included) was first cultivated in Iraq in 1940s and since that time no reports are available on this genus. It seems that $O$. speciosa is unintentionally introduced to Iraq and occurs as casual alien. Many Oenothera species, except $O$. speciosa, are under commercial cultivation (Lady Bird Johnson Wild Flower center, 2001). O. speciosa is known to be tolerant to wide range of ecological conditions (Lim, 2014). Other benefits include using it as showy ground cover, source of food for certain birds and various mammals and a source of several active compounds with medicinal properties (Averett et al., 1987; Marzouk et al., 2009; Lim, 2014). Apart from these benefits, $O$. speciosa in private and common gardens in studied localities showed good competitive and rapid spread characters to become out of control. It seems that the rhizomatous root and its exudates in the species play a key role in this respect. 

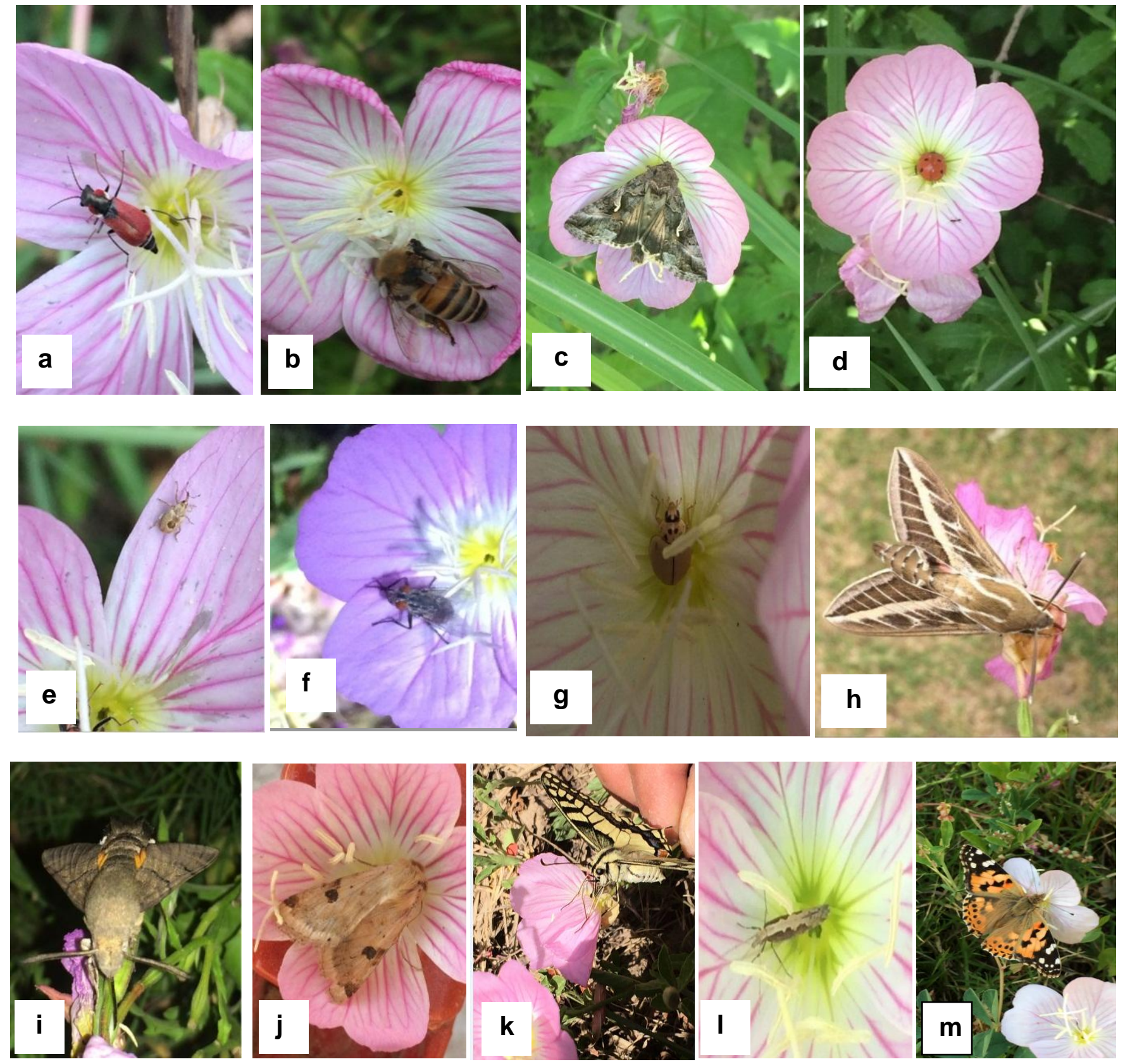

Fig. 6: Insects associated with $O$. speciosa (surface view). a, Anthocomus sp.; b, Apis sp.; c, A. californica; d, Coccinella sp.; e, Curculionidae species; f, Diptera species; g, Harmonia sp.; h, H. livornica; i, M. stellatarum; j, O. lunosa ; k , Papilio sp.; 1, Plutella sp.; m, V.cardui.

The present study reported for the first time from Iraq some detailed information on the morpho-anatomical characters of $O$. speciosa and its faunal associations. Based on leaf anatomy, O. speciosa was recognized here as a C3 plant and this was in agreement with previously published data on photosynthetic pathway in Onagraceae (Watson and Dallwitz, 1992). Raphides reported here (in petiole parenchyma and hairs of style and hypanthium) may represent a defense mechanism against herbivores (Arnott and Webb, 2000). However,
Onagraceae is distinguished by several features, among them the abundance of raphides in vegetative cells (Watson and Dallwitz, 1992; Chen et al., 2007b). This study also recorded for the first time the presence of insect trapping character in $O$. speciosa. Such character was not mentioned before for the genus Oenothera or other members of Onagraceae and this will be beneficial for research on biodiversity, reproductive biology or ecological relations of the genus or its member $O$. speciosa in particular. 

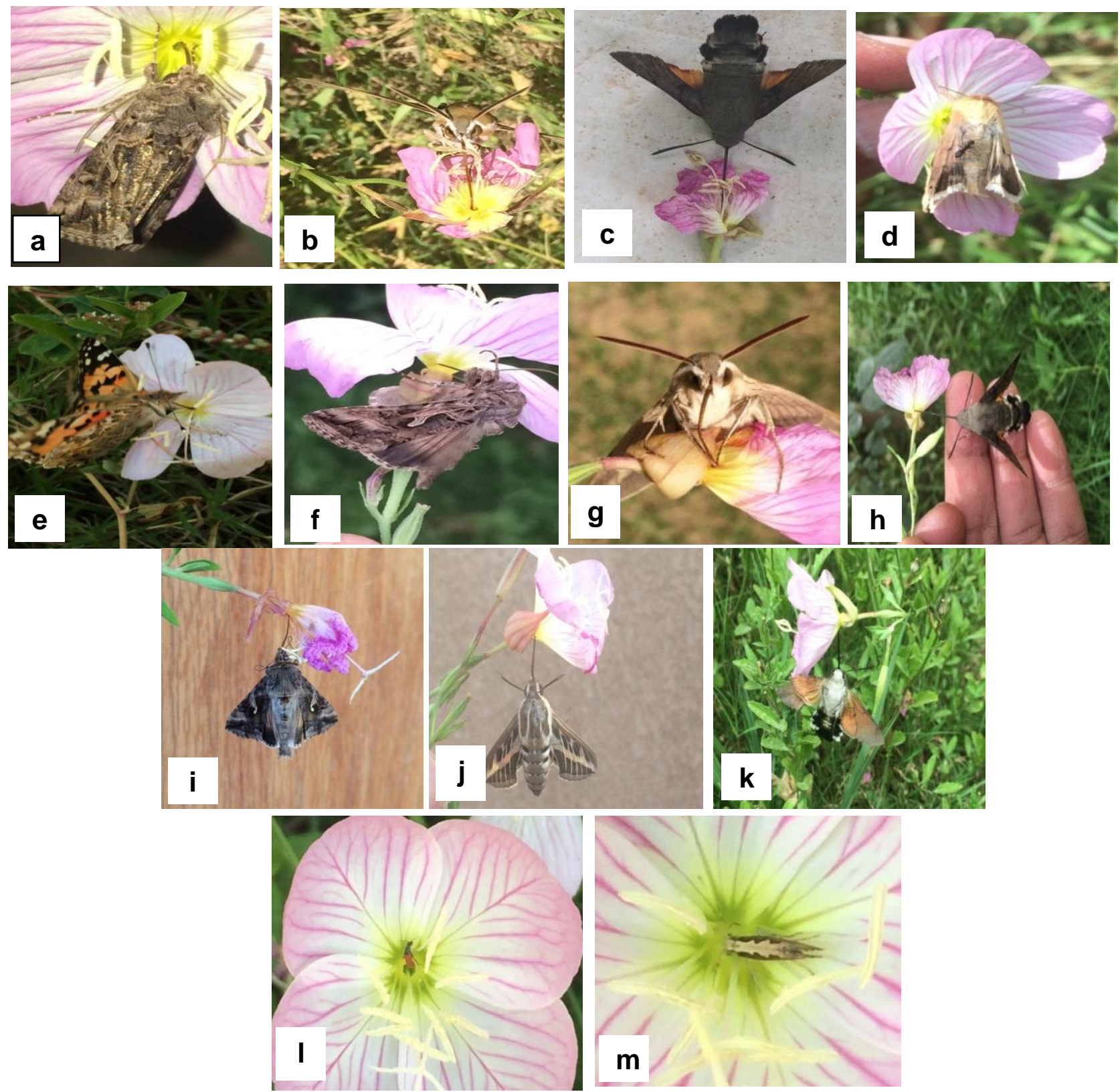

Fig. 7: Insect feeding behavior. a-e, top feeding of A. californica, H. livornica, M. stellatarum, O. lunosa and V. cardui; f-h, lateral feeding of A. californica, H. livornica and M. stellatarum; i-k, trapped (hanged-like appearance) A. californica, H. livornica and M. stellatarum; 1, feeding of Anthocomus (free entry and exit of the whole body ); m, feeding of Plutella (by head entry).
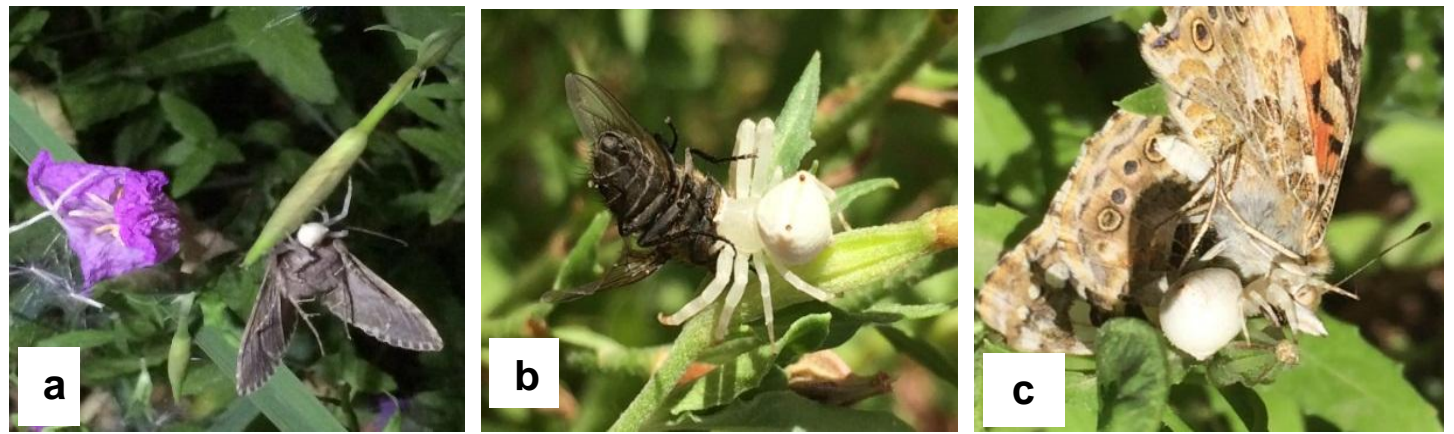

Fig . 8: Insects captured by white spider. a, A. californica; b, Diptera fly; c, V. cardui. 
Concerning fauna associated with $O$. speciosa, members of Lepidoptera ( 7 genera from 5 families) and Coleoptera ( 3 genera from 2 families) are the most common visitors of this plant. In spite of its role in keeping biological balance in various ecosystems (Mirshamsi et al., 2000), white spider in studied area was the main predator of insects feeding on $O$. speciosa, mainly moths, butterflies and bees thus affecting both pollination and biodiversity. However, hovering moths showed antipredator adaptation against white spider by hovering behavior either over or around flowers. Inspite of this character, hovering moths in relation to $O$. speciosa (as trapping plant) are not good pollinators compared with other visiting insects.

\section{Conflict of interest statement}

Authors declare that they have no conflict of interest.

\section{References}

Al-Katib, 2000. Taxonomy of Seed Plants. Ministry of Higher Education and Scientific Research, Dar Alkutib, University of Musel, Iraq. 584p.

Al-Rawi, A., 1964. Wild Plants of Iraq with their Distribution. Ministry of Agriculture and Irrigation, Iraq.

Arnett, R. H., 2000. American Insects: A Handbook of the Insects of America North of Mexico. $2^{\text {nd }}$ Edn. CRC Press, ISBN-10: 0849302129. 947p.

Arnott, H. J., Webb, M. A., 2000. Twinned raphides of calcium oxalate in grape (Vitis): Implications for crystal stability and function . Int. J. Plant Sci. 16(1), 133- 142.

Averett, J. E., Huang, S., Wagner, W., 1988. Flavonoid survey of Oenothera (Onagraceae): Sects.Gauropsis, Hartmannia, Kneiffia, Paradoxus and Xylopleurum . Amer. J. Bot. 75(4), 476- 483.

Averett, J. E., Huang, S., Wagner, W., 1987. Flavonoid analysis of Oenothera speciosa (Onagraceae) South w. Naturalist. 32, 117-120.

Capinera, J. L., 2008. Encyclopedia of Entomology. Springer Science and Business Media . 4346p.

Chakravarty, H. L., 1976. Plant Wealth of Iraq. Ministry of Agriculture and Agrarian Reform, Iraq.

Chamberlain, D. F., 1972. Oenothera L. In: Flora of Turkey and the East Aegean Islands, Vol. 4. Edinburgh University Press, Edinburgh. pp.181-182.

Chapman, R. F., 1998. The Insects: Structure and Function. Cambridge University Press. 770p.

Chen, J., Hoch, P., Wagner, W., 2007a. Flora of China: Oenothera, Vol. 13. Pp.423-426.

Chen, J., Hoch, P., Raven, P., Boufford, D., Wagner, W., 2007b. Onagraceae: In Wu et al. (2007). Flora of China, Vol.13, (Clasiaceae through Araliaceae). Science Press, Beijing and MBG Press. pp.274-400.

Cokendolpher, J. C., Horner, N., Jennings, D. T., 1979. Crab spiders of North Texas (Araneae: philodromidae and thomisidae). J. Kansas Entomol. Soc. 52 (4), 723-734.

Dietrich, W., Wagner, W. L., Raven, P. H., 1997. Systematics of Oenothera Sec. Oenothera subsection Oenothera (Onagraceae). Syst. Bot. Monogr. 50, 1-234.

Evans, A., 2014. Beetles of Eastern North America. Princeton University Press. 537p.

Heath, J., Emmet, A. M., 1983. The Moths and Butterflies of Great Britain and Ireland, Vol. 9 (Shingidae to Noctuidae - Noctuinae and Handeninae) Harley Bouks Pub., U. K.

Heppner, J. B., 2010 . Mannal of Lepidoptera:Classification of Butterflies and Moths of the World. CRC Publisher, ISBN : 0849321549 .

Hilty, J., 2015. Prairie Wild flowers of Illinois. John @illinoiswildflowers.info. Last update 6-8-15. Copy right (2002 - 2015 ) by John Hilty.

Hoch, P. C., Raven, P. H., 1981. Onagraceae. In: Flora of Pakistan (Eds.: Nasir, E., Ali, S.I.). Vol. 139. pp.1-44.

Huang, T.C., Editorial Committee of the Flora of Taiwan, 2003. Flora of Taiwan. $2^{\text {nd }}$ Edn. Vol. 6. Great China Printing Co., Ltd, Taipei. pp.1-343.

Kendall, D. A., 2009. Classification of Insects. Retrieved 9 May 2009.

Lady Bird Johnson Wild Flower, 2001. Oenothera speciosa. Lady Bird Johnson Wildflower Center, 4801 La Cross Avenue, Austin Texas 78739 - 1702. www.wildflower.org

Levin, R, A., Wagner, W., Hoch, P., Nepokroff, M., Pires, J., Zimmer, E., Sytsma, K., 2003. Family-level relationships of Onagraceae based on chloroplast rbcL and ndhF data. Amer. J. Bot. 90, 107-115.

Levin, R. A., Wagner, W., Hoch, P., Hahn, W., Rodriguez, A., Baum, D. A., Katinas, L., Zimmer, E. A., Sytsma, K. J., 2004. Paraphyly in tribe Onagreae: Insights into phylogenetic relationships of Onagraceae based on nuclear and chloroplast sequence data. Syst. Bot. 29(1), 147-164.

Lim, T. K., 2014. Edibil Medicinal and Non-medicinal Plants: Vol. 8: Flowers. Springer Science + Business Media Dordrecht.

Macaulay, D., 2008. Survey of the Lepidoptera Fauna in Wilmore Wilderness Park Report prepared for Alberta Tourism, Parks and Recreation, Resource Management Coordination Branch, Alberta Heritage Information Center, Edmonton, AB. 29p.

Marzouk, M., Moharram, F., EL-Dib, R., El-Shenawy, S., Tawfike, A., 2009. Polyphenolic profile and bioactivity study of Oenothera speciosa Nutt. Aerial Parts. Molecules. 14, 1456-1467.

Matthew, K.M., 1995. An Excursion Flora of Central Tamilnadu. CRC Press. 682p.

Mirshamsi, O., Darvish, J., Goodarzi, H., 2000 . Identification and study of five genera of crab spiders in Khorasan Province (Araneae, Thomisidae). J. Entomol. Soc. Iran. 19 (1-2), 15-30.

Montanari, S., Marconi, G., 2010. New Floristic Records from Romagna. Quad. Studi Nat. Romagna 31, 1-10.

Munz, P. A., 1965. Onagraceae. North American Flora II (5). 
278p.

Press, J . R., Shrestha, K., Suttan, D. A., 2000. Annotated Checklist of the Flowering Plants of Nepal (The Natural History Museum, London). www.floraofNepal.org.

Prigge, A. B., Gibson, A., 2012. Anaturalist 25 Flora of the Santa Monica Mountains and Semi Bills, California, Prigge and Gibion Publisher, Los Angeles. 388p.

Raven, P. H., 2013. Onagraceae. In: Flora of Iraq: Vol . 5, Part 2 (Eds.: Ghazanfar, S., Edmondson, J.). Royal Botanical Gardens, Kew, UK. pp.9-18.

Raven, P. H., 1968. Oenotherea L. In: Flora Europaea, Vol. 2 (Eds.: Tutin, T. G., Haywood, V. H., Burges, N. A., Moore, N. A., Valentine, D. M., Walters, D. H., Webb, S. M.). Cambridge University Press.

Rostanski, K., 1982. The species of Oenothera L. in Britain. Watsonia 14, 1-34.

Rostanski, K., 2006. The occurrence of Oenothera species in Scandinavia. Biodiv. Res. Conserv. 1-2, 64-68.

Shin, H. T., Yi, M., Yoon, J., Sung, J., Kim, Gi, 2012. Status of Alien plant species in the Seongeup folk village in Jeju Island. J. Korean Nature. 5(4), 299-304.

Starr, F., Starr, K., 2011. New Plant Records from Midway Atoll, Maui and Kaho Olawe. Bishop Museum Occasional Papers No. 110. Pp.23-25.

Tobe, H., Wagner, W. L., Chin, H. C., 1987. A systematic and evolutionary study of Oenothera ( Onagraceae ): Seed coat anatomy. Bot. Gaz . 148(2), 235-257.

Vladimirov, V., Oane, F., Tan, K., 2010. New floristic records in the Balkans: 13. Phytologia Balcanica. 16 (1), 143-165.

Wager, W. L., Hoch, P. C., 2007. Onagraceae, Oenothera sect. Hartmannin (Spach) W. L. Wagner \& Hoch. Syst . Bot. Monogr. 83. P.153.

Wagner, W. L., Hoch, P. C., Raven, P. H., 2007. Revised Classification of the Onagraceae-Systematic Botany Monographs. Vol. 83. Pp.1-240.

Watson, L., Dallwitz, M. J., 1992. The Families of Flowering Plants: Description, Identification and Information Retrieval.

\section{How to cite this article:}

Alkhesraji, T. O., Al-abide, N. M., Salih, S. H., 2016. Oenothera speciosa Nutt. (Onagraceae): A new record for the flora of Iraq with reference to its faunal associations and insect trapping attributes. Int. J. Curr. Res. Biosci. Plant Biol. 3(11), 69-78. doi: http://dx.doi.org/10.20546/ijcrbp.2016.311.011 